\title{
Influence of discrete-pulse energy input on the distribution of plant biomass
}

\section{Valerii Myronchuk ${ }^{1}$, Oleksandr Obodovych ${ }^{2}$, Vitalii Sydorenko ${ }^{2}$}

\author{
1 - National University of Food Technologies, Kyiv, Ukraine \\ 2 - Institute of Engineering Thermophysics of the National Academy of Sciences \\ of Ukraine, Kyiv, Ukraine
}

Keywords:

Milling

Biomass

Disperser

Frequency

Granulometry

Article history:

Received

27.01.2019

Received in

revised form

03.06.2019

Accepted

30.09.2019

Corresponding author:

Oleksandr

Obodovych

E-mail:

tdsittf@ukr.net

DOI:

$10.24263 / 2304-$

974X-2019-8-3-

17

\section{Abstract}

Introduction. The aim of this work is to determine the influence of dispersion modes of plant biomass of raw materials in the rotor-pulsating apparatus by the method of discrete-impulse energy input

Materials and methods. The material of the studies was wheat straw and corn stalks, grinded on a disintegrator, which were mixed with water in certain proportions. The suspension was treated in a rotor-pulsating apparatus under different modes. The particle size distribution of the obtained particles was determined by the sieve method and the laser diffraction method.

Results and discussion. It is determined that under the same conditions of treatment granulometric composition of the mixture of milled biomass of corn stalks with water after milling in the rotor-pulsating apparatus has a dispersity of 3-5\% lower than the mixture of wheat. This can be explained by the different strengths of lignocellulosic fibers in the investigated plants.

It was found that with the increase of a solid/water ratio from 1: 5 to $1: 15$, a dispersity of particles is reduced by $35-40 \%$, and from 1: 5 to $1: 10$ by $3-5 \%$. According to the authors, this is due to changes in the viscosity of the solution. Reducing the solid/water ratio from 1:15 to 1:10 for 10 cycles of the dispersion treatment in the rotor-pulsating apparatus leads to a decrease in temperature from 47 to $42^{\circ} \mathrm{C}(\approx 10 \%)$, but the productivity of the equipment increases 1.5-2 times, energy consumption decreases by $25-30 \%$. The optimum parameters for milling of wheat straw or corn stalks in a rotor-pulsating apparatus are: the solid/water ratio is $1: 10$; the shear flow rate is $40 \cdot 10^{3} \mathrm{~s}^{-1}$; the frequency of flow pulsations is $3 \mathrm{kHz}$. The number of processing cycles is $25-30$. It was determined that the granulometric composition of an aqueous dispersion of wheat straw or corn stalks at a solid/water ratio of $1: 10$ and treated in the rotor-pulsating apparatus with the frequency of pulsations of $3 \mathrm{kHz}$, shear flow rate $40 \cdot 10^{3} \mathrm{~s}^{-1}$ for $25-$ 30 cycles allows the conclude that about $50 \%$ of the particles have a size in the range of $30-50 \mu \mathrm{m}$.

Conclusions. Dispertion of plant biomass by the method of discrete-pulse energy input provides for obtaining $80 \%$ of particles with a size of $1-50 \mu \mathrm{m}$. 


\section{- Processes and Equipment-}

\section{Introduction}

In the technology of acid or enzymatic hydrolysis of lignocellulosic feedstock, a pretreatment of plant raw materials for hydrolysis involving the grinding of plant raw materials is a necessary but most energy-consuming step [1]. Mechanical pre-treatment of plant raw materials before the hydrolysis proves mechanical comminution can afford 5-25\% improvement of hydrolysis product and boosts $23-59 \%$ rate of hydrolysis, depending on the milling techniques [2]. A comparison study was performed and it showed that smaller size of corn stover (about 53-75 mm) produced greater outcome by 1.5 -fold than the larger size substrate [3]. The effect of particle size on enzymatic hydrolysis of pretreated Miscanthus x giganteus was determined by Esha Khullar with colleagues. An increasing trend in percent total conversion was observed with decreasing mean particle size. Enzyme hydrolysis of unpretreated biomass samples also resulted in increased total conversions as particle size decreased, although mean conversions (10-20\%) were much lower than for pretreated biomass samples (53-94\%) [4].

The effect of feedstock particle size on dilute acid hydrolysis using Giant Reed (Arundodonax) was studied in the work [5]. Results clearly show a selective hydrolysis of the hemicellulose regardless of the particle size fractions assayed.

Shredded plant biomass is widely used in various fields: for the bioethanol production, fuel pellets, composite building materials, as the filler for filters, for paper production, in agriculture in the form of fertilizers, vitamin and protein feed additives, as well as in the form of biologically as active additives in the food and cosmetics industry [6-10]. Vegetable flour is obtained by grinding of agricultural waste on various types of grinders [11]. Mechanical milling destroys the crystalline structure of cellulose, increases the surface available to cellulolytic enzymes and, as a result, leads to a significant increase in the reactivity of plant raw material $[12,13]$. Fine milling of straw allows increasing the yield of reducing substances in its hydrolysis [14-16]. Milling of plant raw materials can be carried out both in dry and in wet form [17]. Also, using the apparatus is further improving, in particular, the fermentation, the separation of the biomass of yeast, the production of bioethanol.

In order to preserve the quality of the product obtained, it is advisable to use less powerconsuming equipment. Consequently, the intensification of the milling of plant material while simultaneously reducing the power of mechanical impact is an urgent task.

The application of the method of discrete-pulse energy input in the process of dispersion of plant material allows to optimize the technology of bioconversion of lignocellulose with the production of bioethanol and other products.

The idea of the method discrete-pulse energy input is to accumulate (concentrate) in advance the energy permanently introduced and arbitrarily distributed in the working volume at the local discrete points of the system for further impulse realization to achieve the necessary thermophysical effects [18].

Most often, the discrete-pulse energy input method is implemented in rotor-pulsating apparatus of various modifications [19]. They are widely used in various industries, such as food, pharmaceutical, chemical, microbiological, agriculture, etc [20-24].

The use of this equipment in the milling of lignocellulosic raw material may intensify the process, namely, reduce the duration of pretreatment, hydrolysis, and fermentation, increase the amount of reducing substances, reduce energy costs and, in general, make the technology more efficient.

The aim of research is to determine the influence of dispersion modes of plant biomass of raw materials in the rotor-pulsating apparatus by the method of discrete-impulse energy input. 


\section{Materials and methods}

\section{Plant raw materials}

The materials under study were wheat straw and corn stalks pre-grinded in a disintegrator. The particle size of $400 \mu \mathrm{m}$ after grinding was 69 and $75 \% \mathrm{wt}$. in accordance. The resulting mass was mixed with water in the proportions determined by the experimental conditions. The resulting suspension was treated in a rotor-pulsating apparatus under the modes determined by the experimental conditions with subsequent filtration, after which the granulometric composition was determined.

\section{Methods}

Sieve method. Determination of the granulometric composition of straw was carried out by sieve analysis. The weight of the test material was sifted through a set of sieves, and then the percentage content of the residue on each of the sieves relative to the mass of the initial weighting was determined $[25,26]$.

Microscopy. The particle size distribution in the range 1-80 $\mu \mathrm{m}$ was determined by the method of laser diffraction using the laser particle size analyzer Microsizer $201 \mathrm{~A}$. References to the relevant standards in the order of measurements are given in the sources $[27,28]$.

Experimental setup. To prove the proposed assumptions, an experimental rotorpulsating setup for the milling of plant raw materials was designed. The technological scheme of the setup is presented in Figure1.

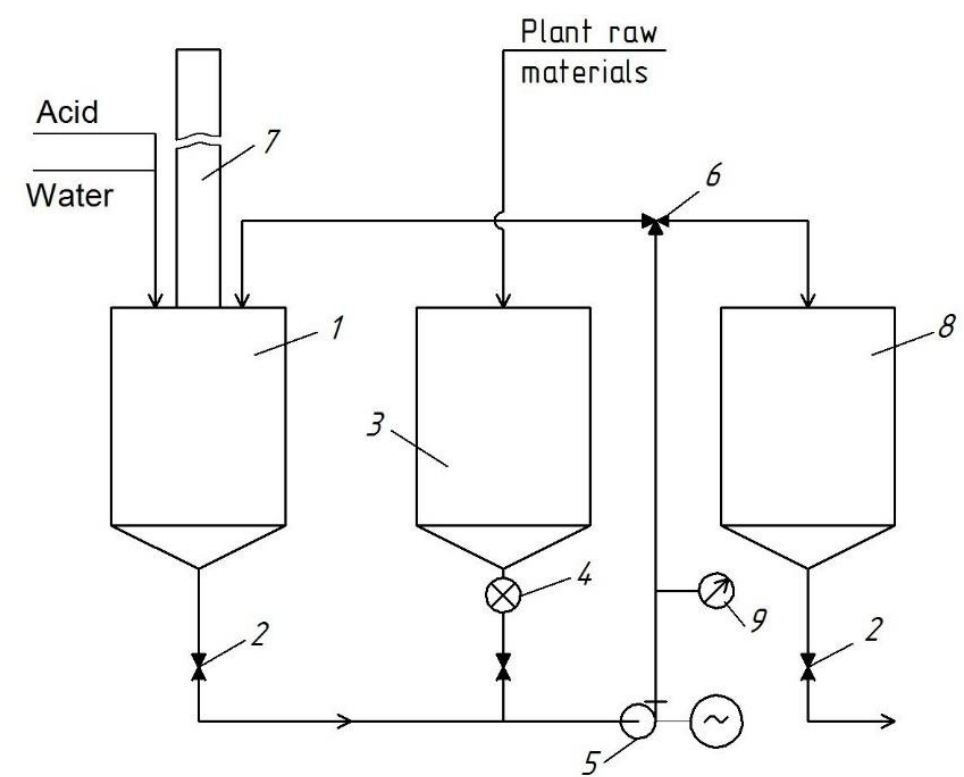

Figure 1. Technological scheme of dispersing of plant raw materials:

1 - receiving tank; 2 - two-way valve; 3 - tank for plant raw materials; 4 - dispenser;

5 - rotor-pulsating apparatus; 6 - three-way valve; 7 - reflux condenser; 8 - collector of dispersed raw materials; 9 - manometer. 
The milling of plant raw materials according to the proposed scheme is as follows. The receiving tank 1 is filling with water. The two-way valve 2 is opening and the prepared solution is fed into rotor-pulsating apparatus 5, which is also a pump. Then, the three-way cock 7 is opened so that the solution returns to the receiving tank 1. For 3-4 cycles of pumping, the dispenser 4 , which in specific proportions feeds the raw material into the solution flow, is turned on.

Solid raw materials are straw, shredded in a disintegrator to particles of not more than 1000 microns in size.

Mixing with the flow, the solid raw material is passing through the rotors and the stator of the rotor-pulsating apparatus, where simultaneously processes of dispersion, dissolution, heating, and hydrolysis occur. These processes occur simultaneously due to the impact of shock waves, interphase turbulence, cavitation, and vortices. It allows destroying the structure of lignocellulose with the removal of lignin and the transfer of crystalline cellulose into an amorphous state, suitable for further processing.

A mixture of liquid solution and plant raw material circulates through the circle: receiving tank 1 - rotor-pulsating apparatus 5 for a few minutes to several hours. During this time, the mixture undergoes dispersing, stirring, dissolving, heating. The complex of such operations prepares the plant material for hydrolysis. The prepared milled mass is sent to collector 9 for further use.

The rotor-pulsating unit of the rotor-pulsation apparatus consists of two rotors connected by screws and representing a single rotor unit, the stator and the impeller of the centrifugal pump.

The rotors have the following design characteristics: the inner radius of the small rotor is $56 \mathrm{~mm}$, the inner radius of the large rotor was $66 \mathrm{~mm}$, the width of the slots is $3.0 \mathrm{~mm}$, the angle between the slots in the shell of $6^{\circ}$, the height of the slot is $5 \mathrm{~mm}$, and the number of slots of rectangular shape is 60 . The range of gap variation between the rotor and the stator is $\delta=0.3-0.5 \mathrm{~mm}$. Structural characteristics of the stator are as follows: the radius of the stator is $61 \mathrm{~mm}$, the width of slots is $3.0 \mathrm{~mm}$, the height of the slots is $5 \mathrm{~mm}$, and the number of slots of rectangular shape is 60 .

\section{Results and discussion}

\section{Dry pre-treatment by disintegrator}

In the first stage of studies, the straw of wheat and corn stalks were pre-treated in a disintegrator Д3-300/1 (operated at speed of $3000 \mathrm{rpm}$, power consumption $3 \mathrm{~kW} / \mathrm{h}$ for half an hour) to particles of not more than $1000 \mu \mathrm{m}$ in size. The granulometric composition of the plant raw material after treatment in the disintegrator is given in Table 1.

Table 1

Granulometric composition of wheat straw and corn stalks ( $\%$ by weight) after treatment in a disintegrator

\begin{tabular}{|c|c|c|c|c|c|c|}
\hline Type of plant raw material & \multicolumn{7}{|c|}{ Particle size, $\boldsymbol{\mu m}$} \\
\cline { 2 - 7 } & $>80$ & $80-125$ & 125 & 200 & $200-300$ & $<400$ \\
\hline Straw of wheat & 2 & 4 & 5 & 8 & 10 & 69 \\
\hline Corn stalks & 1 & 3 & 4 & 6 & 11 & 75 \\
\hline
\end{tabular}


The granulometric composition of wheat straw and corn stalks after treatment in the disintegrator is almost unchanged. The content of particles larger than $400 \mu \mathrm{m}$ is about $70 \%$. In the course of further research, the resulting crushed mass from various types of raw materials was mixed with water at a solid/water ratio of $1: 5 ; 1: 10 ; 1: 15$.

\section{Wet milling by discrete-pulse energy input}

The resulting dispersions are processed by the method of discrete-pulse energy input in a rotor-pulsating apparatus consisting of one stator and two rotors.

The intensity of processing of water dispersion of wheat straws or corn stalk in the rotorpulsating apparatus is determined by the follows parameters:

Frequency of flow pulsations

$$
f=\omega \cdot n,
$$

where $\omega$ is the rotational speed of rotor unit, rps; $n$ is a number of holes in the rotor and stator.

Flow shear rate

$$
v=\frac{\omega \cdot R}{\mu},
$$

where $\mathrm{R}$ is internal radius of the rotor, $\mathrm{m} ; \mu$ is the gap between rotor and stator.

The mechanisms of discrete-pulse energy input in a rotor-pulsating apparatus were the frequency of flow pulsations and the flow shear rate of the treated medium, which were respectively $1 \mathrm{kHz}$ and $20 \cdot 10^{3} \mathrm{~s}^{-1}$.

An important value characterizing the passage of the medium through the rotorpulsating apparatus is the number of cycles of treatment. One cycle is the time taken for the entire volume of the treated medium to pass through the working bodies of the rotor-pulsating apparatus is taken.

Table 2 shows the granulometric composition of the aqueous dispersion of wheat straw in a solid/water ratio of $1: 5 ; 1: 10 ; 1: 15$ and treated in a rotor-pulsating apparatus for 10 cycles.

Table 2

Granulometric composition ( $\%$ by weight) of the aqueous dispersion of wheat straw at a solid/water ratio of $1: 5 ; 1: 10 ; 1: 15$.

\begin{tabular}{|c|c|c|c|c|c|}
\hline \multirow{2}{*}{ Solid/water ratio } & \multicolumn{5}{|c|}{ Particle size, $\boldsymbol{\mu m}$} \\
\cline { 2 - 6 } & $<80$ & $80-125$ & $125-200$ & $300-400$ & $>400$ \\
\hline $1: 5$ & 44 & 18 & 9 & 9 & 20 \\
$1: 10$ & 42 & 17 & 9 & 11 & 21 \\
$1: 15$ & 31 & 11 & 10 & 14 & 33 \\
\hline
\end{tabular}

Similar studies have been conducted for the aqueous dispersion of corn stalks. The data is shown in Table 3.

Table 3

Granulometric composition ( $\%$ by weight) of aqueous dispersion of corn stalks at a solid/water ratio of $1: 5 ; 1: 10 ; 1: 15$.

\begin{tabular}{|c|c|c|c|c|c|}
\hline \multirow{2}{*}{ Solid/water ratio } & \multicolumn{5}{|c|}{ Particle size, $\boldsymbol{\mu m}$} \\
\cline { 2 - 6 } & $<80$ & $80-125$ & $125-200$ & $300-400$ & $>400$ \\
\hline $1: 5$ & 36 & 10 & 15 & 14 & 25 \\
$1: 10$ & 35 & 9 & 13 & 16 & 27 \\
$1: 15$ & 19 & 7 & 17 & 21 & 36 \\
\hline
\end{tabular}


Under the same conditions of treatment granulometric composition of the mixture of milled biomass of corn stalks with water after milling in the rotor-pulsating apparatus has a dispersity of $3-5 \%$ lower than the mixture of wheat. This can be explained by the different strengths of lignocellulosic fibers in the investigated plants.

It was also found that with the increase of a solid/water ratio from 1:5 to 1:15, a dispersity of particles is reduced by $35-40 \%$, and from $1: 5$ to $1: 10$ by $3-5 \%$. According to the authors, this is due to changes in the viscosity of the solution. A aqueous dispersion of wheat straw at a solid/water ratio of 1:5 is a viscous suspension, which is difficult to pump by rotor-pulsating apparatus. In this connection, the dissipation of mechanical energy into heat is carried out.

For 10 cycles, the solution treated in the rotor-pulsating apparatus was heated from 17 to $47^{\circ} \mathrm{C}$.

The graph of the temperature change of the water dispersion of wheat straw treated in the rotor-pulsating apparatus from the number of processing cycles and the solid/water ratio is shown in Figure 2.

The change in the temperature of the aqueous dispersion of corn stalks from the number of processing cycles and the solid/water ratio when milling in the rotor-pulsating apparatus has a similar dynamics with wheat straw.

Reducing the solid/water ratio from 1:15 to 1:5 allows to increase the viscosity of the solution, and hence the temperature. This factor is important not only in the process of lignocellulosic raw materials milling, but also in its bioconversion.

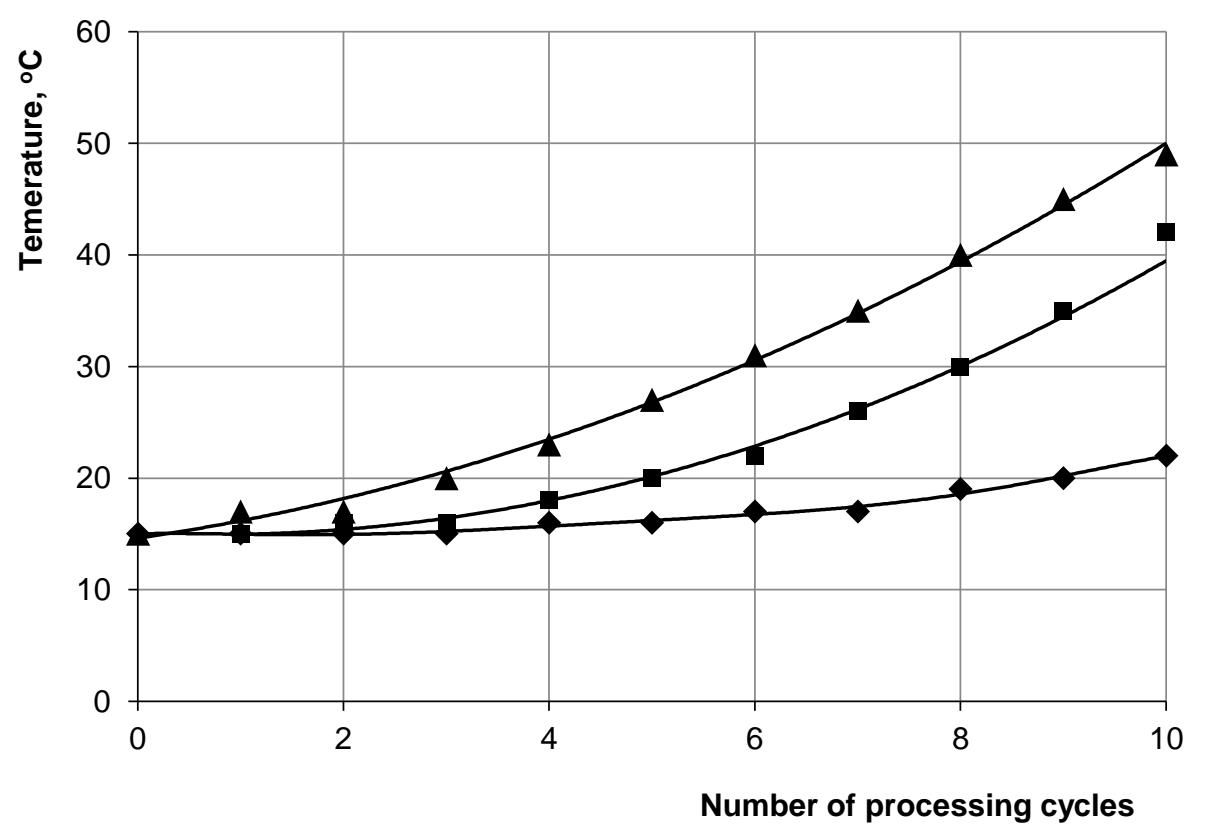

Figure 2. Dependence of temperature change of water dispersion of wheat straw on dispersion in the rotor-pulsating apparatus from the number of cycles of treatment and the solid/water ratio:

$$
\bullet-1: 15 ; \text { - }-1: 10 ; \Delta-1: 5 \text {. }
$$




\section{-Processes and Equipment-}

Reducing the solid/water ratio from $1: 15$ to $1: 10$ for 10 cycles of the dispersion treatment in the rotor-pulsating apparatus leads to a decrease in temperature from 47 to $42{ }^{\circ} \mathrm{C}$ $(\approx 10 \%)$, but the productivity of the equipment increases $1.5-2$ times, energy consumption decreases by $25-30 \%$.

The temperature of the water dispersion of wheat straw or corn stalks in a solid/water ratio of $1: 15$, treated in the rotor-pulsating apparatus in 10 cycles, rises from 17 to $22{ }^{\circ} \mathrm{C}$, at the same time with a solid/water ratio of $1: 10$ from 17 to $42{ }^{\circ} \mathrm{C}$, with a solid/water ratio of 1:5 from 17 to $47^{\circ} \mathrm{C}$.

The analysis and comparison of the resulted experimental data allow concluding, that further studies are appropriate to behave with a solid/water ratio of 1:10.

For a study $1 \mathrm{~kg}$ of milled in a disintegrator wheat straw or corn stalks was mixed with 10 liters of water and treated in a rotor-pulsating apparatus for 1 to 50 cycles at a constant flow shear rate $\left(20 \times 10^{3} \mathrm{~s}^{-1}\right)$ and a variable frequency of pulsations $(1,3$, and $5 \mathrm{kHz})$.

The change in the granulometric composition of the obtained straw wheat mass is shown in Figure 3.

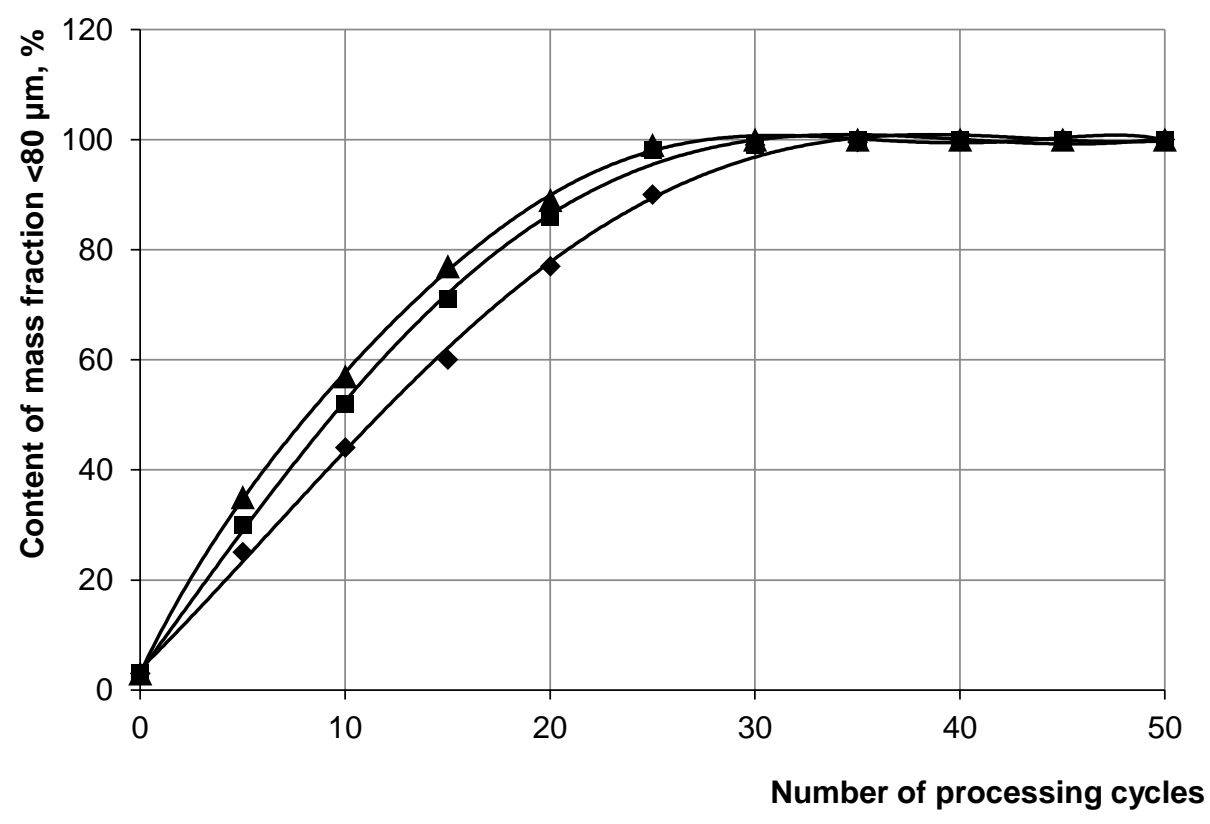

Figure 3. Dependence of the content of the mass fraction of the milled wheat straw less than 80 $\mu \mathrm{m}$ on the number of processing cycles and the frequency of pulsations:

$$
\checkmark-1 \mathrm{kHz} \text { - }-3 \mathrm{kHz} ; \Delta-5 \mathrm{kHz} \text {. }
$$

When processing the water dispersion of wheat straw in a rotor-pulsating apparatus with a frequency of pulsations equal to $1 \mathrm{kHz}, 42$ cycles are required to reach $100 \%$ of the particles in less than $80 \mu \mathrm{m}$. With an increase in the frequency of pulsations from 1 to $3 \mathrm{kHz}$, the number of cycles decreases to $30(\approx 30 \%)$.

When the frequency of pulsations is changed from 1 to $5 \mathrm{kHz}$, the number of cycles decreases to $27(\approx 35 \%)$. 
An increase in the frequency of pulsations from 3 to $5 \mathrm{kHz}$ is associated with additional energy costs and practically does not affect the number of processing cycles. Given this, further studies were carried out at a frequency of pulsations of $3 \mathrm{kHz}$.

The dependence of the content of the mass fraction of the particle fraction of the dispersed mass of corn stalks is less than $80 \mu \mathrm{m}$ on the number of processing cycles and the frequency of pulsations is similar to wheat straw.

Further studies have been conducted to study an influence of the flow shear rate in the rotor-pulsating apparatus and the number of processing cycles at the fractional granulometric composition.

The flow shear rate varied from $20 \cdot 10^{3} \mathrm{~s}^{-1}$ to $50 \cdot 10^{3} \mathrm{~s}^{-1}$.

The dynamics of change in the fractional composition of treated plant raw material is presented in Figure 4.

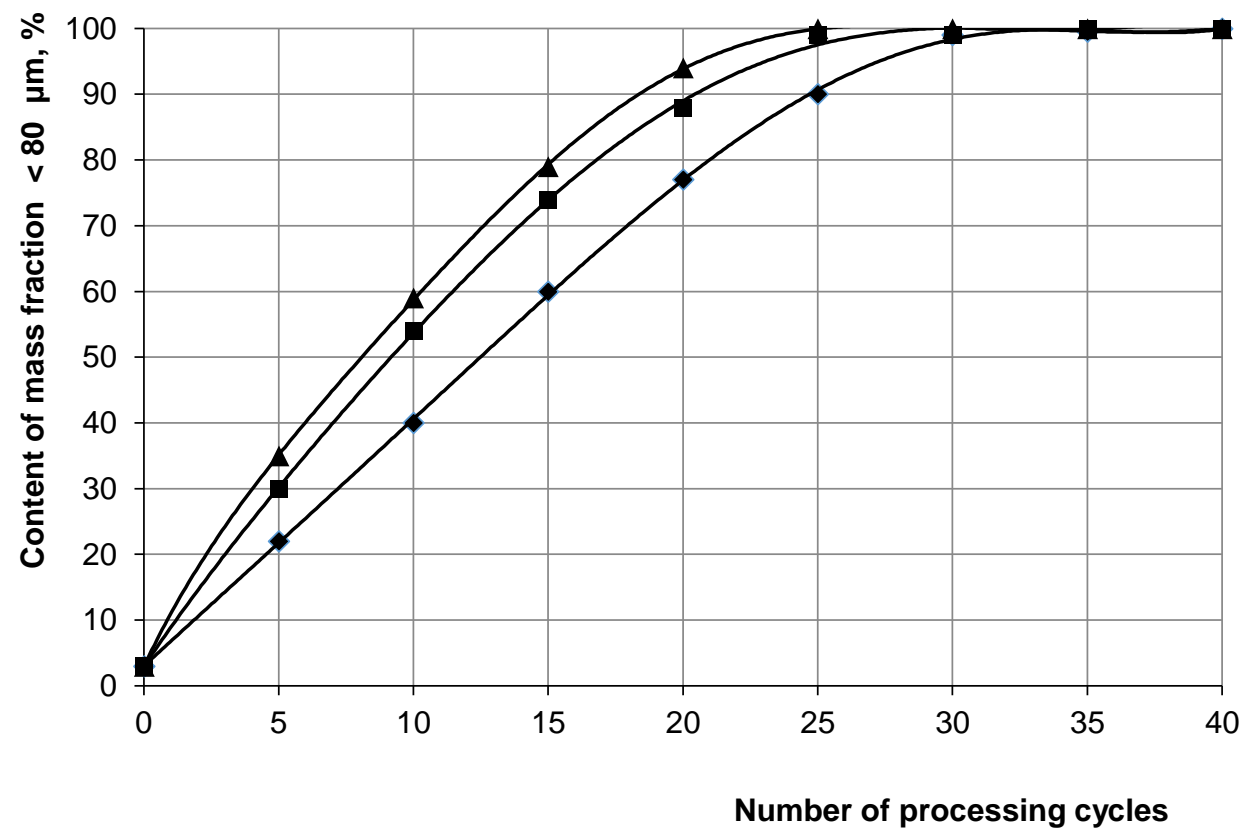

Figure 4 The dependence of the content of the mass fraction of the dispersed mass of wheat straw is less than $80 \mu \mathrm{m}$ on the number of processing cycles and flow shear rate: $-20 ; \square-40 ; \Delta-50 \cdot 10^{3} s^{-1}$.

The change in the flow shear rate significantly affects the particle distribution than the frequency of pulsations. The number of processing cycles decreases by 5-7\%. The most efficient treatment of the medium in the rotor-pulsating apparatus for the flow shear rate is $40 \cdot 10^{3} \mathrm{~s}^{-1}$.

The optimum parameters for milling of wheat straw or corn stalks in a rotor-pulsating apparatus are: the solid/water ratio is $1: 10$; the shear flow rate is $40 \cdot 10^{3} \mathrm{~s}^{-1}$; the frequency of flow pulsations is $3 \mathrm{kHz}$. The number of processing cycles is $25-30$. 


\section{- Processes and Equipment-}

The particle size distribution in the interval 1- 80 microns was of interest. Data are presented in Table 4.

Table 4

Granulometric composition of fraction $<\mathbf{8 0}$ microns of dispersed wheat straw (corn stalks)

(\% by weight)

\begin{tabular}{|l|c|c|c|c|c|}
\hline \multirow{2}{*}{ Type of plant raw material } & \multicolumn{5}{|c|}{ Particle size, $\mu \mathrm{m}$} \\
\cline { 2 - 6 } & $1-5$ & $5-10$ & $10-30$ & $30-50$ & $50-80$ \\
\hline Straw of wheat & 7 & 9 & 12 & 53 & 19 \\
Corn stalks & 6 & 10 & 13 & 49 & 23 \\
\hline
\end{tabular}

Analysis of the granulometric composition of an aqueous dispersion of wheat straw or corn stalks at a solid/water ratio of 1:10 and treated in the rotor-pulsating apparatus with the frequency of pulsations of $3 \mathrm{kHz}$, shear flow rate $40 \cdot 10^{3} \mathrm{~s}^{-1}$ for $25-30$ cycles allows the conclude that about $50 \%$ of the particles have a size in the range of $30-50 \mu \mathrm{m}$.

Such a extended interface contributes to the intensification of the process of bioconversion of the plant raw material.

The results obtained were compared with those of pre-treatment of a water dispersion of rice straw by techniques of wet disk milling(WDM), hot-compressed water treatment (HCWT), and dry ball milling (DBM) described in a work [29] and with date obtained during the processing of corn stover in the ball mill [30].

The results obtained in this work were also compared with results of dry pre-treatment of wheat straw by various techniques. A large range of wheat-straw powders was produced: from coarse (median particle size $800 \mu \mathrm{m})$ to fine particles $(50 \mu \mathrm{m})$ using sieve based grindings, then ultra-fine particles $20 \mu \mathrm{m}$ by jet milling and $10 \mu \mathrm{m}$ by ball milling [31]. In another study, four mechanical deconstruction methods were compared at lab scale: BM (ball mill), VBM (vibratory ball mill), CM (centrifugal mill) and JM (jet mill) [32].

The results of the comparison indicate that the combination of dry pre-treatment of wheat straw or corn stalks in a disintegrator, followed by treatment of the aqueous suspension of the obtained biomass by the method of discrete-pulse energy input allows obtaining a higher degree of dispersion of the particles.

\section{Conclusions}

The use of the method of discrete-pulse energy input in the process of milling of biomass of plant raw material on the on the example of straw wheat and corn stalks provides for obtaining $77-80 \%$ of particles of dispersed biomass in the size of 1-50 microns.

\section{Refrences}

1. Mustafa Vohra, Jagdish Manwar, Rahul Manmode, Satish Padgilwar, Sanjay Patil (2014), Bioethanol production: Feedstock and current technologies, Journal of Environmental Chemical Engineering, 2, pp. 573-584.

2. Hendriks A, Zeeman G. (2009), Pretreatments to enhance the digestibility of lignocellulosic biomass, Bioresour Technol, 100, pp. 10-8. 
3. Zeng M, Mosier N, Huang C-P,et al. (2007), Microscopic examination of changes of plant cell structure in corn stover due to hot water pretreatment and enzymatic hydrolysis, Biotechnol Bioeng, 97, pp. 265-78.

4. Esha Khullar, Bruce S. Dien, Kent D. Rausch, M.E. Tumbleson, Vijay Singh (2013), Effect of particle size on enzymatic hydrolysis of pretreated Miscanthus, Industrial Crops and Products. 44, pp. 11-17. https://doi.org/10.1016/j.indcrop.2012.10.015

5. Ivone Torrado, Filipa Bandeira, Anatoly A. Shatalov, FlorbelaCarvalheiro, Luís C. Duarte (2014), The Impact of Particle Size on the DiluteAcid Hydrolysis of Giant Reed Biomass, Electronic Journal of Energy \& Environment, 2(1), pp. 1-9. DOI 10.7770/ejee-V2N1art598.

6. Seung Gon Wi, In Seong Choi, Kyoung Hyoun Kim, Ho Myeong Kim, and Hyeun-Jong Bae. (2013), Bioethanol production from rice straw by popping pretreatment, Biotechnol Biofuels, 6, p. 166.

7. Ríos-Badrán I. M., Luzardo-Ocampo I., García-Trejo J. F., Santos-Cruz J. and GutiérrezAntonio C. (2019). Production and characterization of fuel pellets from rice husk and wheat straw. Renewable Energy, 145, pp. 500-507. DOI: 10.1016/j.renene.2019.06.048

8. Bouasker Marwen, Belayachi Naima, Hoxha Dashnor, and Al-Mukhtar1 Muzahim. (2014), Physical Characterization of Natural Straw Fibers as Aggregates for Construction Materials, Applications Materials (Basel). 7(4), pp. 3034-3048, DOI: 10.3390/ma7043034

9. Ashraf Ghanem, Mohammed Haggag (2015), Assessment of the Feasibility of Using Filter Made of Rice Straw for Treating Aquaculture Effluents in Egypt, Resources and Environment, 5(5), pp. 135-145, DOI: 10.5923/j.re.20150505.01

10. Tripathi Sandeep, Bhardwaj Nishi K. (2013), Blending study of Banana with wheat straw and bagasse to enhance physical strength properties of paper, IPPTA: Quarterly Journal of Indian Pulp and Paper Technical Association, 25(2), pp. 121-126.

11. Mayer-Laigle Claire, Rajaonarivony Karine, Blanc Nicolas, Xavier Rouau Xavier. (2018), Comminution of Dry Ligno-cellulosic Biomass: Part II. Technologies, Improvement of Milling Performances, and Security Issues.Bioengineering, MDPI, 5(3), DOI: 10.3390/bioengineering5030050

12. Bridgeman, T. G., Darvell, L. I., Jones, J. M., Williams, P. T., Fahmi, R., Bridgwater, A. V., et al. (2007), Influence of particle size on the analytical and chemical properties of two energy crops, Fuel, 86(1-2), pp. 60-72.

13. Maier, G., Zipper, P., Stubicar, M., \& Schurz, J. (2005), Amorphization of different cellulose samples by ball milling, Cellulose Chemistry and Technology, 39(3-4), pp. 167-177.

14. Nurtdinov R.M., Valeeva R.T., Mukhachev S.G., Kharina M.V. (2011), Predvaritelnaia obrabotka rastitelnogo syria i otkhodov selskokhoziaistvennogo proizvodstva s tseliu povysheniia vykhoda redutsiruiushchikh veshchestv, Vestnik Kazanskogo tekhnologicheskogo universiteta, 9, pp. 264-267

15. Barakat A., Mayer-Laigle C., Solhy A., Arancon R.A.D., de Vries H., Luque R. (2014), Mechanical pretreatments of lignocellulosic biomass: towards facile and environmentally sound technologies for biofuels production, RSC Advances, 4(89), pp. 48109-48127, DOI: 10.1039/C4RA07568D

16. Hendriks A.T.W.M., Zeeman G. (2009), Pretreatments to enhance the digestibility of lignocellulosic biomass, Bioresour Technol, 100(1), pp. 10-18.

17. Florian Monla, Cecilia Sambusiti, and Abdellatif Barakat (2019), Comparison of Dry Versus Wet Milling to Improve Bioethanol or Methane Recovery from Solid Anaerobic Digestate, Bioengineering, 6(3), 80, https://doi.org/10.3390/bioengineering6030080

18. Dolinskii A.A., Ivanitskii G.K. (2008), Teplomassoobmen $i$ gidrodinamika $v$ parozhidkostnykh dispersnykh sredakh. Teplofizicheskie osnovy diskretno-impulsnogo vvoda energii, Naukova dumka, Kyiv. 


\section{- Processes and Equipment-}

19. Promtov M.A. (2001), Pulsatsionnye apparaty rotornogo tipa: teoriia i praktika, Mashinostroenie-1, Moskow.

20. Dolinskii A.A. (2015), Mikro- $i$ nanourovnevye protsessy $v$ tekhnologiiakh DIVE, Akademperiodika, Kyiv.

21. Dolinskyi A.A., Obodovych O.M., Sydorenko V.V., Husiatynska N.A. (2018), Realii cohodennia ta perspektyvy maibutnoho pidhotovky pytnoi i tekhnolohichnoi vody, Naukovi pratsi NUKhT, 24(2), pp. 247-255.

22. Obodovich A.N., Sydorenko V.V. (2018), Assessment of the efficiency of oxygen absorption in rotor-pulsating apparatus, Acta Periodica Technologica, 49, pp. 117-125.

23. Obodovich A.N., Lymar, A.N., Kostik, S.I., Sidorenko, V.V. (2015), Snizhenie energozatrat pri pererabotke krokhmalosoderzhashchikh sred metodom diskretno - impulsnogo vvoda energii, Promyshlennaia teplotekhnika, 37(1), pp. 44-50.

24. Obodovich A.N., Sidorenko V.V., Lymar A.Iu., Mironets I.N. (2013), Ispolzovanie diskretno-impulsnogo metoda vvoda energii (DIVE) dlia intensifikatsii prigotovleniia zhidkikh kormov dlia selskokhoziaistvennykh zhivotnykh na osnove bardy, Vibratsii $v$ tekhnitsi ta tekhnolohiiakh, 70(2), pp. 190-195.

25. Bitra Venkata, Womac Alvin, Yang Yuechuan, Miu Petre, Igathinathane,C. Chevanan Nehru, Sokhansanj Shahab (2011), Characterization of wheat straw particle size distributions as affected by knife mill operating factors, Biomass \& Bioenergy, 35, pp. 36743686. DOI 10.1016/j.biombioe.2011.05.026.

26. Wills B.A., Finch J.A. (2016), Particle Size Analysis, Wills' Mineral Processing Technology, 91-107, DOI: 10.1016/b978-0-08-097053-0.00004-2

27. Philo Morse, MS, and Andrew Loxley (2009), Light Microscopic Determination of Particle Size Distribution in an Aqueous Gel, Drug Delivery Technology, 9(5), pp. 44-49.

28. Allen T. (2003), Particle size analysis by image analysis. Powder Sampling and Particle Size Determination, pp. 142-207, DOI: 10.1016/b978-044451564-3/50005-x

29. Hideno A., Inoue H., Tsukahara K., Fujimoto S., Minowa T., Inoue S., Sawayama S. (2009), Wet disk milling pretreatment without sulfuric acid for enzymatic hydrolysis of rice straw, Bioresource Technology, 100(10), pp. 2706-2711, DOI: 10.1016/j.biortech.2008.12.057

30. Lin Zengxiang, Huang He, Zhang Hongman, Zhang Lin, Yan Lishi, Chen Jingwen. (2010), Ball Milling Pretreatment of Corn Stover for Enhancing the Efficiency of Enzymatic Hydrolysis. Applied biochemistry and biotechnology,162, pp. 1872-80, DOI: 10.1007/s12010-010-8965-5

31. Silva G.G.D., Couturier M., Berrin J.-G., Buléon A., Rouau X. (2012), Effects of grinding processes on enzymatic degradation of wheat straw, Bioresource Technology, 103(1), pp. 192-200, DOI: 10.1016/j.biortech.2011.09.073

32. Licari A., Monlau F., Solhy A., Buche P., Barakat A., (2016), Comparison of various milling modes combined to the enzymatic hydrolysis of lignocellulosic biomass for bioenergy production: Glucose yield and energy efficiency, Energy, 102(C), pp. 335-342, DOI: 10.1016/j.energy.2016.02.083. 